\title{
Assessment of radionuclide concentration in three crustaceans species of the bay of Bengal
}

\author{
C.K. HASAN $^{1}$, M. ZAFAR ${ }^{1}$, M.I. CHOWDHURY ${ }^{2}$, M. KAMAL ${ }^{2}$
}

(Manuscript received 12 June 2006, accepted 16 September 2006)

\begin{abstract}
The natural $\left({ }^{226} \mathrm{Ra},{ }^{228} \mathrm{Th},{ }^{232} \mathrm{Th}\right.$ and $\left.{ }^{40} \mathrm{~K}\right)$ and anthropogenic $\left({ }^{137} \mathrm{Cs}\right)$ radionuclides concentrations in three crustaceans species (Penaeus monodon, Metapenaeus monoceros and Panulirus versicolor), collected from the bay of Bengal, were determined with an aim of assessing any internal radiation hazard due to consumption of the shell fishes and establishing a database for radioactivity levels of the species. Very low level of radioactivity was observed in all the species. The average activity of ${ }^{226} \mathrm{Ra}$ observed in $P$. monodon was $1.21 \pm 0.27 \mathrm{~Bq} \mathrm{~kg}^{-1} \mathrm{fw}$; in $M$. monoceros was $0.70 \pm 0.08 \mathrm{~Bq} \mathrm{~kg}^{-1} \mathrm{fw}$, and in Panulirus versicolor was $1.04 \pm 0.09 \mathrm{~Bq}$ $\mathrm{kg}^{-1} \mathrm{fw}$. The activity of ${ }^{232} \mathrm{Th}$ observed in these species was $1.30 \pm 0.37,0.76 \pm 0.34$ and $1.32 \pm 0.70 \mathrm{~Bq} \mathrm{~kg}{ }^{-1} \mathrm{fw}$, and ${ }^{228}$ Th was $0.55 \pm 0.26,0.31 \pm 0.14$ and $0.74 \pm 0.22 \mathrm{~Bq}$ $\mathrm{kg}^{-1} \mathrm{fw}$, respectively. The average activity of ${ }^{40} \mathrm{~K}$ observed in these species was 12.56 $\pm 1.18,6.38 \pm 1.02$ and $10.07 \pm 1.52 \mathrm{~Bq} \mathrm{~kg}^{-1} \mathrm{fw}$, respectively. The activity of radiocaesium $\left({ }^{137} \mathrm{Cs}\right)$ was below detection limit. The results indicate that the natural and artificial radionuclides observed in three crustaceans species are safe for human health. A significant relationship was observed between ${ }^{226} \mathrm{Ra}$ and ${ }^{232} \mathrm{Th}$ in both the P. monodon $(\mathrm{r}=0.839, \mathrm{p} \leq 0.05, \mathrm{df}=4)$ and the Panulirus versicolor $(\mathrm{r}=0.906, \mathrm{p} \leq$ $0.05, \mathrm{df}=4)$.
\end{abstract}

Keywords: radionuclide / shrimp / lobster / bay of Bengal

RÉSUMÉ Mesure de la concentration de radionucléides dans trois espèces de crustacés du golfe du Bengale.

Les concentrations des radionucléides naturels $\left({ }^{226} \mathrm{Ra},{ }^{228} \mathrm{Th},{ }^{232} \mathrm{Th}\right.$ et $\left.{ }^{40} \mathrm{~K}\right)$ et anthropogéniques $\left({ }^{137} \mathrm{Cs}\right)$ ont été mesurées dans trois espèces de crustacés (Penaeus monodon, Metapenaeus monoceros et Panulirus versicolor) récoltés dans le golfe du Bengale, dans le but d'évaluer le risque de contamination interne lié à la consommation de crustacés et d'établir une base de données pour les niveaux de radioactivité de ces espèces. On a observé un niveau de radioactivité très bas dans toutes les espèces. L'activité moyenne de ${ }^{226} \mathrm{Ra}$ observé dans Penaeus monodon était de $1,21 \pm 0,27 \mathrm{~Bq} \mathrm{~kg}{ }^{-1}$ poids frais ; de $0,70 \pm 0,08 \mathrm{~Bq} \mathrm{~kg}^{-1}$ dans Metapenaeus monoceros, et de $1,04 \pm 0,09 \mathrm{~Bq} \mathrm{~kg}^{-1}$ de poids frais dans Panulirus versicolor. L'activité de ${ }^{232}$ Th mesurée dans ces espèces est de $1,30 \pm 0,37,0,76 \pm 0,34$ et 1,32 \pm $0,70 \mathrm{~Bq} \mathrm{~kg}{ }^{-1}$ de poids frais, celle de ${ }^{228} \mathrm{Th}, 0,55 \pm 0,26,0,31 \pm 0,14$ et $0,74 \pm$ $0,14 \mathrm{~Bq} \mathrm{~kg}^{-1}$ de poids frais respectivement. L'activité moyenne de ${ }^{40} \mathrm{~K}$ mesurée dans ces espèces est de $12,56 \pm 1,18,6,38 \pm 1,02$ et $10,07 \pm 1,52 \mathrm{~Bq} \mathrm{~kg}^{-1}$ de poids frais, respectivement. L'activité du ${ }^{137} \mathrm{Cs}$ était au-dessous de la limite de détection. Les

${ }^{1}$ Institute of Marine Sciences, University of Chittagong, Chittagong 4331, Bangladesh.

${ }^{2}$ Radioactivity Testing and Monitoring Laboratory, Bangladesh Atomic Energy Commission, Chittagong Medical College Campus, P.O. Box No. 1352, Chittagong, Bangladesh. 
résultats indiquent que les radionucléides naturels et artificiels mesurés dans trois espèces de crustacés sont sans danger pour la santé humaine. Une relation significative entre ${ }^{226} \mathrm{Ra}$ et ${ }^{232} \mathrm{Th}$ a été observée dans les deux espèces Penaeus monodon $(r=0,839, \mathrm{p} \leq 0,05, \mathrm{df}=4)$ et Panulirus versicolor $(\mathrm{r}=0,906, \mathrm{p} \leq 0,05, \mathrm{df}=4)$.

\section{Introduction}

Bangladesh is a fisheries products exporting country, and it exports frozen shrimp to about thirty countries of the world. During the year 2002-2003, the country exported 56.48 million pound of shrimps to the overseas countries (EPB, 2005). The continental shelf of the bay of Bengal is very wide, which is the possible indication of its high productivity (Zafar, 2000). Four fishing grounds have been identified in the bay, which are potential reserves for shrimps and lobsters. A total of thirty two shrimp and six lobster species have been reported from Bangladesh water territory of the bay of Bengal (Ahmed, 1983). Six penaeid species, namely Penaeus merguiensis (banana shrimp), P. monodon (tiger shrimp), P. indicus (white shrimp), P. semisulcatus (green tiger shrimp), Metapenaeus monoceros (brown shrimp), and M. brevicornis are of commercial importance.

Aquatic organisms may concentrate both natural and artificial radionuclides by direct absorption from the water and feeding (Polikarpov, 1966). Since the oceans are considered as a safe place for radionuclides disposal over the years by the nuclear powered countries, this radioactivity ultimately finds its way to human body (Clark, 1989). As the shrimps and lobsters have the demand of domestic consumption and export value, consideration of human health safety is an important issue. Therefore, the study on radionuclide concentration in marine shrimps and lobsters was considered to be worthwhile for the country. Besides, since no such work was previously conducted on P. monodon and Panulirus versicolor, the present study was deemed to be necessary. The objective of the present work was to detect and measure the natural $\left({ }^{226} \mathrm{Ra},{ }^{228} \mathrm{Th},{ }^{232} \mathrm{Th}\right.$ and $\left.{ }^{40} \mathrm{~K}\right)$ and anthropogenic $\left({ }^{137} \mathrm{Cs}\right)$ radionuclides in marine shrimps and lobsters of the bay of the Bengal with an aim to protect the human from internal radiation hazard, if any, and to establish the data base for radioactivity levels of the species.

\section{Materials and methods}

The samples were collected from the deep sea at latitude: $21^{\circ} 04^{\prime} \mathrm{N}$ and longitude: $91^{\circ} 20^{\prime} \mathrm{E}$ (Fig. 1), by bottom trawl net (Fig. 2) using a commercial fishing vessel during September 2005. The species were Penaeus monodon (Fig. 3), Metapenaeus monoceros (Fig. 4), and Panulirus versicolor (Fig. 5), identified by following Motoh (1981) and Pal (2001). The collected samples were properly cleaned to remove sand, weed and other unwanted objects with fresh water, 


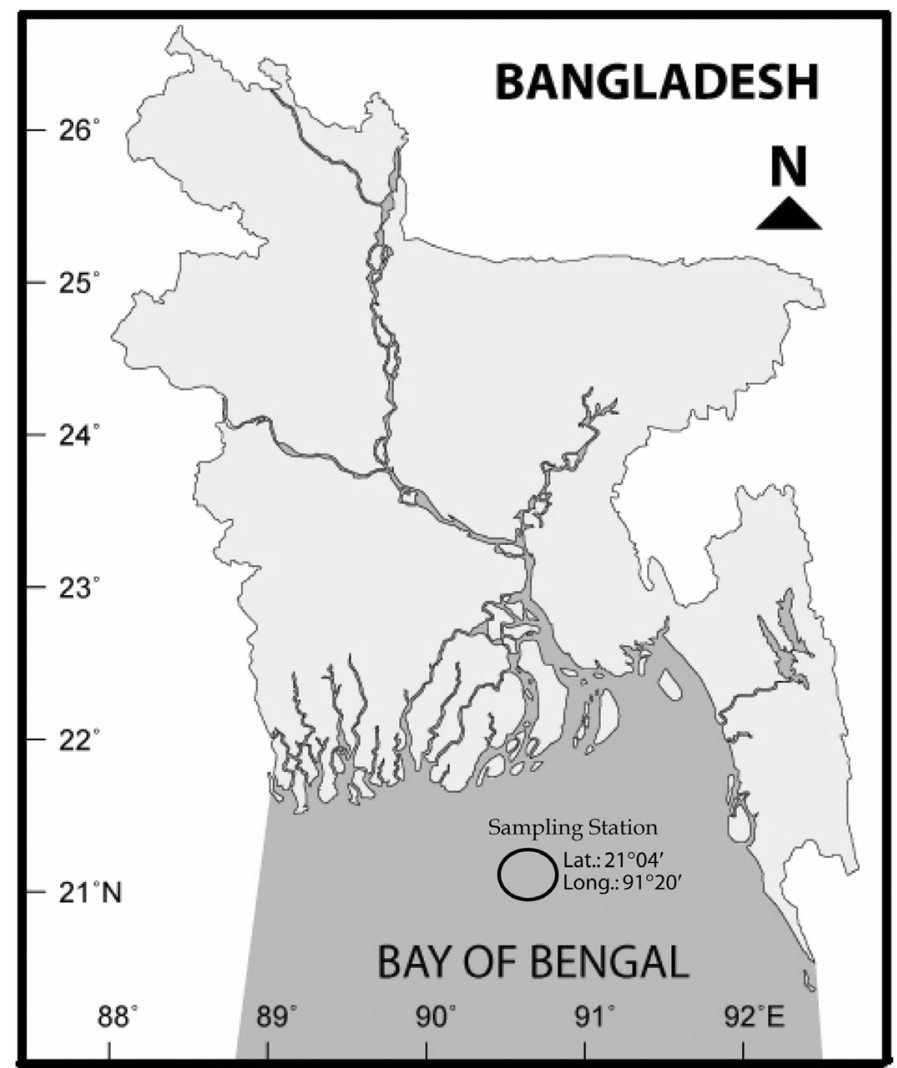

Figure 1 - Sampling location in the bay of Bengal.

Localisation des prélèvements dans le golfe du Bengale.

thereafter, de-heading the shrimps and lobsters. For each category of species, 5 samples of equal weight were prepared. To prepare 5 samples of each category of species, a total of 2-4 kg of fresh samples were taken. To prepare $91 \mathrm{~g}$ dry sample of $P$. monodon, it required to take $400 \mathrm{~g}$ of fresh sample. And the 5 dry samples (each with $91 \mathrm{~g}$ ) were prepared from $2.0 \mathrm{~kg}$ of fresh samples of P. monodon. Likewise, 5 dry samples (each with $119.7 \mathrm{~g}$ dry sample) of M. monoceros were prepared from $3.25 \mathrm{~kg}$ of fresh samples. To prepare 5 dry samples (each with $85.6 \mathrm{~g}$ dry sample) of Panulirus versicolor, a total of $2.0 \mathrm{~kg}$ fresh samples were taken. All the samples were put into woven and dried at $120-150{ }^{\circ} \mathrm{C}$ for $2-3$ days until complete dehydration. The dried samples were ground to powder with mortar and pestle, and then kept in cylindrical plastic screw-cap containers and sealed. 


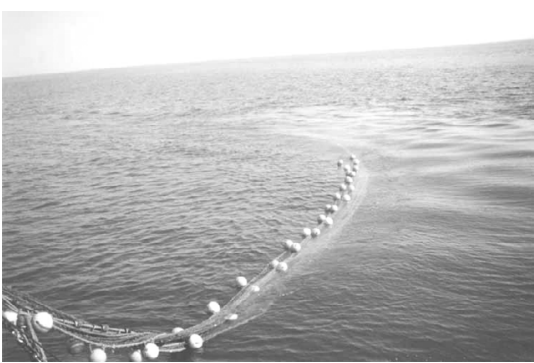

Figure 2-Bottom trawl net in operation for collecting shrimps and lobsters from the bay of Bengal.

Filet de chalut utilisé pour collecter les crevettes et les langoustines dans le golfe du Bengale.

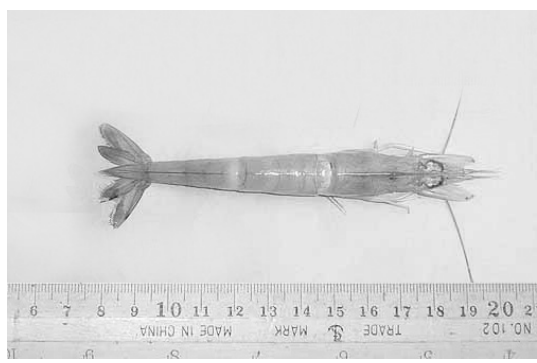

Figure 4-Metapenaeus monoceros collected from the bay of Bengal.

Metapenaeus monoceros collecté dans le golfe du Bengale.

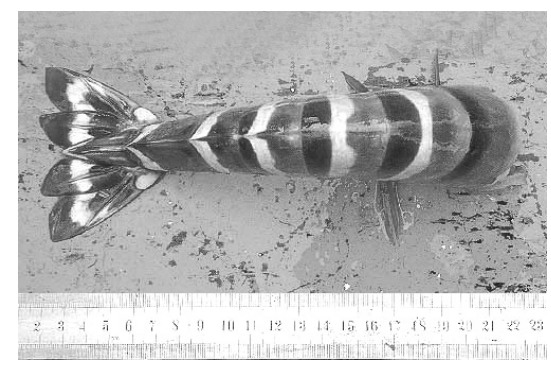

Figure 3 - Penaeus monodon collected from the bay of Bengal.

Penaeus monodon collecté dans le golfe du Bengale.

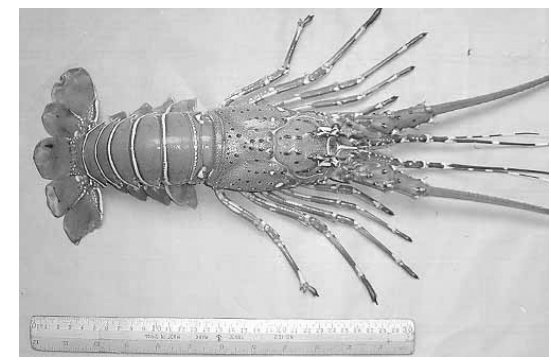

Figure 5 - Panulirus versicolor collected from the bay of Bengal.

Panulirus versicolor collecté dans le golfe du Bengale.

The measurements were made one month later to maintain radioactive secular equilibrium between ${ }^{226} \mathrm{Ra}$ and ${ }^{232} \mathrm{Th}$ series and most of their daughters (Schotzing and Debertin, 1983).

The detection and measurement of radionuclides in the shell fish samples were carried out by gamma-spectrometry using a $100 \mathrm{~cm}^{3}$ intrinsic p-type coaxial HPGe detector with a relative efficiency of $20 \%$ and a resolution of $1.83 \mathrm{keV}$ for the peak of $1332 \mathrm{keV}$ of ${ }^{60} \mathrm{Co}$. The detector was connected to an 8192-channel computer analyzer. Efficiency calibration was carried out using standard samples (AQCS, 1996). The ${ }^{226} \mathrm{Ra}$ activity was determined from gamma-ray energy of ${ }^{214} \mathrm{~Pb}$ at $352 \mathrm{keV}$ and ${ }^{214} \mathrm{Bi}$ at $609 \mathrm{keV} ;{ }^{232} \mathrm{Th}$ activity was measured from gamma-ray energy of 
${ }^{228} \mathrm{Ac}$ at 911 and $969 \mathrm{keV} ;{ }^{228} \mathrm{Th}$ measured from ${ }^{208} \mathrm{Tl}$ at $583.19 \mathrm{keV} ;{ }^{40} \mathrm{~K}$ activity at $1460 \mathrm{keV}$; and ${ }^{137} \mathrm{Cs}$ activity was measured at $661 \mathrm{keV}$ gamma-ray energy (Debertin and Helmer, 1988).

\section{Results and discussion}

The activity of ${ }^{226} \mathrm{Ra}$ in $P$. monodon (tiger shrimp) ranged from 0.77 to $1.49 \mathrm{~Bq}$ $\mathrm{kg}^{-1}$ fresh weight (fw) with a mean of $1.21 \pm 0.27 \mathrm{~Bq} \mathrm{~kg}^{-1} \mathrm{fw}$; in M. monoceros (brown shrimp) 0.57 to $0.80 \mathrm{~Bq} \mathrm{~kg}^{-1}$ fw with a mean of $0.70 \pm 0.08 \mathrm{~Bq} \mathrm{~kg}^{-1} \mathrm{fw}$, and in Panulirus versicolor (lobster) 0.90 to $1.14 \mathrm{~Bq} \mathrm{~kg}^{-1} \mathrm{fw}$ with a mean of $1.04 \pm$ $0.09 \mathrm{~Bq} \mathrm{~kg}^{-1} \mathrm{fw}$. The activity concentration of ${ }^{232} \mathrm{Th}$ ranged from 0.77 to $1.75 \mathrm{~Bq} \mathrm{~kg}^{-1} \mathrm{fw}$ with a mean of $1.30 \pm 0.37 \mathrm{~Bq} \mathrm{~kg}^{-1} \mathrm{fw}$ in tiger shrimp; 0.45 to $1.22 \mathrm{~Bq} \mathrm{~kg}^{-1} \mathrm{fw}$ with a mean of $0.76 \pm 0.34 \mathrm{~Bq} \mathrm{~kg}^{-1} \mathrm{fw}$ in brown shrimp; and 0.26 to $1.80 \mathrm{~Bq} \mathrm{~kg}^{-1} \mathrm{fw}$ with a mean of $1.32 \pm 0.70 \mathrm{~Bq} \mathrm{~kg}^{-1} \mathrm{fw}$ in lobster. The activity of ${ }^{228} \mathrm{Th}$ ranged from 0.21 to $0.75 \mathrm{~Bq} \mathrm{~kg}^{-1}$ fw with a mean of $0.55 \pm 0.26 \mathrm{~Bq} \mathrm{~kg}^{-1}$ fw in tiger shrimp; 0.21 to $0.56 \mathrm{~Bq} \mathrm{~kg}^{-1} \mathrm{fw}$ with a mean of $0.31 \pm 0.14 \mathrm{~Bq} \mathrm{~kg}^{-1} \mathrm{fw}$ in brown shrimp; and 0.41 to $1.02 \mathrm{~Bq} \mathrm{~kg}^{-1}$ fw with a mean of $0.74 \pm 0.22 \mathrm{~Bq} \mathrm{~kg}^{-1}$ fw in lobster. The activity of ${ }^{40} \mathrm{~K}$ ranged from 11.23 to $14.07 \mathrm{~Bq} \mathrm{~kg}^{-1}$ fw with a mean of $12.56 \pm 1.18 \mathrm{~Bq} \mathrm{~kg}^{-1} \mathrm{fw}$ in tiger shrimp; 4.92 to $7.27 \mathrm{~Bq} \mathrm{~kg}^{-1}$ fw with a mean of $6.38 \pm 1.02 \mathrm{~Bq} \mathrm{~kg}^{-1} \mathrm{fw}$ in brown shrimp; and 8.57 to $12.13 \mathrm{~Bq} \mathrm{~kg}^{-1} \mathrm{fw}$ with a mean of $10.07 \pm 1.52 \mathrm{~Bq} \mathrm{~kg}^{-1} \mathrm{fw}$ in lobster. Among the three species, the maximum concentration of ${ }^{226} \mathrm{Ra}$ and ${ }^{40} \mathrm{~K}$ was occupied by the tiger shrimp, and the lobster topped in the concentration of ${ }^{232} \mathrm{Th}$ and ${ }^{228} \mathrm{Th}$. The brown shrimp showed the lowest activity of all the investigated radionuclides (Tab. I). The concentration of artificial radionuclides $\left({ }^{137} \mathrm{Cs}\right)$ was found below detection limit in all the species.

The findings of the present study may be compared with the previous study of Alam et al. (1995). They recorded that the activity of ${ }^{226} \mathrm{Ra},{ }^{232} \mathrm{Th}$, and ${ }^{40} \mathrm{~K}$ was $0.37 \pm 0.09,0.52 \pm 0.12$ and $7.32 \pm 0.88 \mathrm{~Bq} \mathrm{~kg}^{-1} \mathrm{fw}$ in M. monoceros; $0.11 \pm 0.01$, $0.36 \pm 0.10$ and $16.71 \pm 1.78 \mathrm{~Bq} \mathrm{~kg}^{-1} \mathrm{fw}$ in $P$. indicus, respectively. The values are more or less approximated to present values. In another study, Alam et al. (1999) estimated the concentration of ${ }^{226} \mathrm{Ra}$ was $4.30 \pm 1.90 \mathrm{~Bq} \mathrm{~kg}^{-1}$ fw in whole soft tissues (WST) and $14.1 \pm 7.4 \mathrm{~Bq} \mathrm{~kg}^{-1} \mathrm{fw}$ in shells; ${ }^{232} \mathrm{Th}$ was $2.60 \pm 1.90 \mathrm{~Bq} \mathrm{~kg}^{-1}$ fw in WST and $8.5 \pm 2.1 \mathrm{~Bq} \mathrm{~kg}^{-1}$ fw in shells; and ${ }^{40} \mathrm{~K}$ was $80.00 \pm 16.5 \mathrm{~Bq} \mathrm{~kg}^{-1}$ fw in WST and $137 \pm 34 \mathrm{~Bq} \mathrm{~kg}^{-1} \mathrm{fw}$ in hard shells of Perna viridis, which are much higher than the present study. The higher values in Perna viridis may be attributed to its hard shell, because hard shell contains higher concentrations of ${ }^{226} \mathrm{Ra},{ }^{232} \mathrm{Th}$ and ${ }^{40} \mathrm{~K}$, which is supported by the study of Blanchard and Oakes (1965). In Acetes shrimps, the average activity of ${ }^{226} \mathrm{Ra},{ }^{228} \mathrm{Th},{ }^{232} \mathrm{Th}$, and ${ }^{40} \mathrm{~K}$ was found $0.98 \pm 0.05,1.29 \pm 0.04,1.47 \pm 0.06$, and $20.10 \pm 0.2 \mathrm{~Bq} \mathrm{~kg}^{-1}$ fw (RTML, 


\section{TABLEAU I}

Radionuclide concentration of three crustaceans species of the bay of Bengal. Concentration des radionucléides dans trois espèces de crustacés du Golfe du Bengale.

\begin{tabular}{|c|c|c|c|c|c|c|}
\hline \multirow[t]{2}{*}{ Name of Species } & \multirow[t]{2}{*}{ Code } & \multicolumn{5}{|c|}{ Activity $\left(\mathrm{Bq} \mathrm{kg}^{-1}\right)$ fresh weight (fw) } \\
\hline & & ${ }^{137} \mathrm{Cs}$ & ${ }^{226} \mathrm{Ra}$ & ${ }^{232} \mathrm{Th}$ & ${ }^{228} \mathrm{Th}$ & ${ }^{40} \mathrm{~K}$ \\
\hline \multirow{6}{*}{$\begin{array}{l}\text { Penaeus } \\
\text { monodon }\end{array}$} & pm1 & BDL & $0.77 \pm 0.15$ & $0.77 \pm 0.14$ & $0.34 \pm 0.06$ & $14.07 \pm 2.75$ \\
\hline & $\mathrm{pm} 2$ & BDL & $1.29 \pm 0.25$ & $1.34 \pm 0.25$ & $0.21 \pm 0.04$ & $11.23 \pm 2.35$ \\
\hline & pm3 & BDL & $1.15 \pm 0.20$ & $1.48 \pm 0.28$ & $0.71 \pm 0.14$ & $12.62 \pm 2.55$ \\
\hline & $\mathrm{pm} 4$ & BDL & $1.49 \pm 0.30$ & $1.75 \pm 0.32$ & $0.75 \pm 0.15$ & $11.59 \pm 2.40$ \\
\hline & pm5 & BDL & $1.33 \pm 0.26$ & $1.16 \pm 0.20$ & $0.75 \pm 0.15$ & $13.30 \pm 2.65$ \\
\hline & Mean & BDL & $1.21 \pm 0.27$ & $1.30 \pm 0.37$ & $0.55 \pm 0.26$ & $12.56 \pm 1.18$ \\
\hline \multirow{6}{*}{$\begin{array}{l}\text { Metapenaeus } \\
\text { monoceros }\end{array}$} & $\mathrm{mm} 1$ & BDL & $0.57 \pm 0.11$ & $0.45 \pm 0.09$ & $0.23 \pm 0.04$ & $7.26 \pm 1.69$ \\
\hline & $\mathrm{mm} 2$ & BDL & $0.70 \pm 0.14$ & $0.57 \pm 0.11$ & $0.25 \pm 0.04$ & $4.92 \pm 1.22$ \\
\hline & $\mathrm{mm} 3$ & BDL & $0.80 \pm 0.16$ & $1.02 \pm 0.15$ & $0.28 \pm 0.05$ & $7.27 \pm 1.70$ \\
\hline & $\mathrm{mm} 4$ & BDL & $0.74 \pm 0.15$ & $0.52 \pm 0.10$ & $0.21 \pm 0.04$ & $5.76 \pm 1.40$ \\
\hline & $\mathrm{mm} 5$ & BDL & $0.70 \pm 0.14$ & $1.22 \pm 0.24$ & $0.56 \pm 0.11$ & $6.71 \pm 1.59$ \\
\hline & Mean & BDL & $0.70 \pm 0.08$ & $0.76 \pm 0.34$ & $0.31 \pm 0.14$ & $6.38 \pm 1.02$ \\
\hline \multirow{6}{*}{$\begin{array}{l}\text { Panulirus } \\
\text { versicolor }\end{array}$} & pv1 & BDL & $0.90 \pm 0.16$ & $0.26 \pm 0.05$ & $0.41 \pm 0.08$ & $8.57 \pm 1.93$ \\
\hline & pv2 & BDL & $1.11 \pm 0.18$ & $1.79 \pm 0.34$ & $1.02 \pm 0.17$ & $10.13 \pm 2.18$ \\
\hline & pv3 & BDL & $1.00 \pm 0.17$ & $0.95 \pm 0.79$ & $0.65 \pm 0.12$ & $12.13 \pm 2.48$ \\
\hline & pv4 & BDL & $1.14 \pm 0.20$ & $1.80 \pm 0.34$ & $0.76 \pm 0.15$ & $8.63 \pm 1.94$ \\
\hline & pv5 & BDL & $1.03 \pm 0.16$ & $1.79 \pm 0.34$ & $0.84 \pm 0.16$ & $10.91 \pm 2.30$ \\
\hline & Mean & BDL & $1.04 \pm 0.09$ & $1.32 \pm 0.70$ & $0.74 \pm 0.22$ & $10.07 \pm 1.52$ \\
\hline
\end{tabular}

*BDL $=$ Below Detection Limit.

2001), which are more or less similar to that of present study. In Crassostrea sp., the activity of ${ }^{226} \mathrm{Ra},{ }^{232} \mathrm{Th}$ and ${ }^{40} \mathrm{~K}$ was recorded $11.5 \pm 2.0,7.7 \pm 1.5$ and $24 \pm$ $3.4 \mathrm{~Bq} \mathrm{~kg}^{-1} \mathrm{fw}$, respectively (Chowdhury et al., 2003), which showed higher trend of radionuclide concentration than the present investigation. Zafar et al. (2004) recorded that the activity of ${ }^{226} \mathrm{Ra},{ }^{232} \mathrm{Th}$ and ${ }^{40} \mathrm{~K}$ was found $2.77 \pm 0.17,3.98 \pm$ 0.26 , and $109.58 \pm 3.65 \mathrm{~Bq} \mathrm{~kg}^{-1} \mathrm{fw}$, respectively in the edible parts of Scylla serrata; but the activity found in the shrimps and lobsters are less than that of $S$. serrata. The previous workers found that the concentration of radiocaesium $\left({ }^{137} \mathrm{Cs}\right)$ in crustaceans was below detection limit, which coincides with the present experiment.

Among the radionuclides, ${ }^{40} \mathrm{~K}$ contributed maximum activity (79\%), while the fall-out radiocaesium ${ }^{137} \mathrm{Cs}$ shared no activity in all the investigated shrimps and lobsters (Fig. 6). The ${ }^{40} \mathrm{~K}$ represents more than $80 \%$ in aquatic components (Lambrechts et al., 1992). 


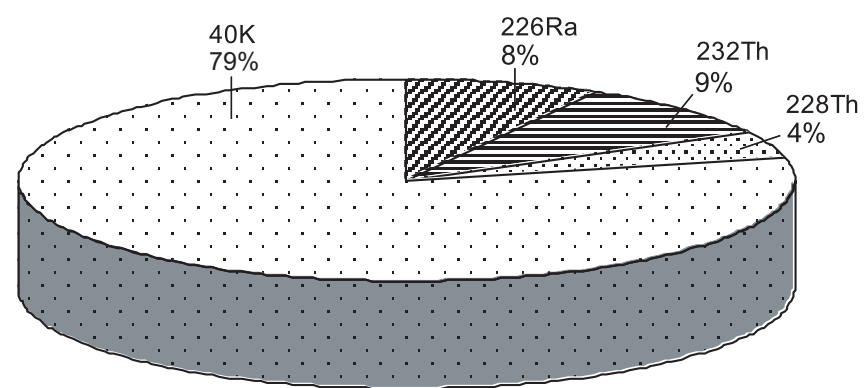

Figure 6 - Percentage contribution of radionuclides concentrated in shrimps and lobsters.

Distribution des radionucléides dans les crevettes et les langoustines.

A significant relationship was observed between ${ }^{226} \mathrm{Ra}$ and ${ }^{232} \mathrm{Th}$ in both the tiger shrimp $(r=0.839, p \leq 0.05, d f=4)$ and the lobster $(r=0.906, p \leq 0.05, d f=4)$. A significant relationship was found between ${ }^{232} \mathrm{Th}$ and ${ }^{40} \mathrm{~K}(\mathrm{r}=0.859, \mathrm{p} \leq 0.05$, $\mathrm{df}=4$ ) in tiger shrimp. The relationship between ${ }^{232} \mathrm{Th}$ and ${ }^{228} \mathrm{Th}$ was found highly significant in both the brown shrimp $(\mathrm{r}=0.846, \mathrm{p} \leq 0.05, \mathrm{df}=4)$ and the lobster $(\mathrm{r}=0.906, \mathrm{p} \leq 0.05, \mathrm{df}=4)$. A significant relationship was also observed between ${ }^{226} \mathrm{Ra}$ and ${ }^{228} \mathrm{Th}(\mathrm{r}=0.816, \mathrm{p} \leq 0.05, \mathrm{df}=4)$ in lobster (Tabs. II-IV).

Table II

Correlation matrix between different variables of radionuclides in $P$. monodon.

Corrélations entre les concentrations de radionucléides dans $P$. monodon.

\begin{tabular}{lcccc}
\hline & ${ }^{226} \mathrm{Ra}$ & ${ }^{232} \mathrm{Th}$ & ${ }^{228} \mathrm{Th}$ & \\
\hline${ }^{226} \mathrm{Ra}$ & 1 & & & \\
${ }^{232} \mathrm{Th}$ & $0.839^{*}$ & 1 & 1 & \\
${ }^{228} \mathrm{Th}$ & 0.485 & 0.492 & 0.167 & 1 \\
${ }^{40} \mathrm{~K}$ & 0.563 & $0.859^{*}$ &
\end{tabular}

* At $\mathrm{p} \leq 5 \%$, the tabulated value of $\mathrm{r}$ is 0.811 .

Table III

Correlation matrix between different variables of radionuclides in $M$. monoceros. Corrélations entre les concentrations de radionucléides dans $M$. monoceros.

\begin{tabular}{lcccc}
\hline & ${ }^{226} \mathrm{Ra}$ & ${ }^{232} \mathrm{Th}$ & ${ }^{228} \mathrm{Th}$ & \\
\hline${ }^{226} \mathrm{Ra}$ & 1 & & & \\
${ }^{232} \mathrm{Th}$ & 0.491 & 1 & 1 & \\
${ }^{228} \mathrm{Th}$ & 0.071 & $0.846^{*}$ & -0.378 & 1 \\
${ }^{40} \mathrm{~K}$ & -0.694 & -0.412 & & \\
\hline
\end{tabular}

* At $\mathrm{p} \leq 5 \%$, the tabulated value of $\mathrm{r}$ is 0.811 . 
Table IV

Correlation matrix between different variables of radionuclides in Panulirus versicolor. Corrélations entre les concentrations de radionucléides dans Panulirus versicolor.

\begin{tabular}{lcccc}
\hline & ${ }^{226} \mathrm{Ra}$ & ${ }^{232} \mathrm{Th}$ & ${ }^{228} \mathrm{Th}$ & \\
\hline${ }^{226} \mathrm{Ra}$ & 1 & & & \\
${ }^{232} \mathrm{Th}$ & $0.906^{*}$ & 1 & 1 & \\
${ }^{228} \mathrm{Th}$ & $0.816^{*}$ & $0.906^{*}$ & 0.706 & 1 \\
${ }^{40} \mathrm{~K}$ & 0.534 & 0.462 & & \\
\hline
\end{tabular}

$*$ At $\mathrm{p} \leq 5 \%$, the tabulated value of $\mathrm{r}$ is 0.811 .

\section{Conclusion}

The results achieved through this experiment indicate that very trace amount of natural and anthropogenic radionuclides are concentrated in the investigated shrimps and lobsters of the bay of Bengal, which are safe for the human consumption. The research breakthrough will assist the government and other agency, while dealing with export and import of such shrimps and lobsters from other countries. The data may be useful guideline for the researchers working on radioecology and marine radioactivity. Similar works on other commercially important shrimps and lobsters of the bay of Bengal could be carried out with a view to preparing a full-set of database on marine shell fishes of the country.

\section{REFERENCES}

Ahmed M.K. (1983) A Checklist of the Prawn Fauna of Bangladesh with Some New Records. Res. Rep. No.7, Freshwater Fish Research Station, Comilla, Bangladesh, p. 9.

Alam M.N., Chowdhury M.I., Kamal M., Ghose S. (1995) Radioactivity in Marine Fish of the bay of Bengal, Appl. Radiat. Isot. 46(5), 363-364.

Alam M.N., Chowdhury M.I., Kamal M., Ghose S., Matin A.K.A., Ferdousi G.S.M. (1999) Radionuclide Concentration in Mussels Collected from the Southern Coast of Bangladesh, $J$. Environm. Rad. 47, 201-212.

AQCS (1996) Preparation and Certification of IAEA Gamma Spectrometry Reference Materials. IAEA/RL/ 148, Analytical Quality Control Services, IAEA, Vienna, Austria.

Blanchard R.L., Oakes D. (1965) Relationship between uranium and radium in coastal marine shells and their environment, J. Geophys. Res. 70, 2911-2921.

Chowdhury M.I., Kamal M., Alam M.N., Aftabuddin S., Zafar M. (2003) Environmental radioactivity of the St. Martin's Island, Radioprotection 39(1), 13-21.

Clark R.V. (1989) Marine Pollution, 2nd edn. Clareton Press, Oxford, pp. 1-220.

Debertin K., Helmer R.G. (1988) Gamma and X-ray Spectrometry with Semiconductor Detectors. Elsevier, Amsterdam.

EPB (2005) Shrimps and Fish from Bangladesh [online]. Available at http://www.epb.gov.bd (10 February 2006). 
Lambrechts A., Foulquier I., Laplace J.G. (1992) Natural Radioactivity in the Components of the Main France River, Radiat. Protect. Dosim. 45(1/4), 253-256.

Motoh H. (1981) Studies on the Fisheries Biology of the giant tiger prawn, Penaeus monodon in the Philippines. SEAFDEC Aquaculture Department, Philippines, p. 112.

Pal S.K. (2001) Shrimp and Lobster Biology. Dhaka, Bangladesh, p. 236.

Polikarpov G.G. (1966) Radioecology of Aquatic Organisms (The accumulation and biological effect of radioactive substances), translated by V. Schultz, A.W. Klamant Jr. Reinhold Book Division, NY, p. 314.

RTML (2001) Radionuclide Concentrations, Proximate Composition and Population Dynamics of Acetes shrimps in the Kutubdia Channel, Bangladesh. RTML Report on Radioactivity, Chittagong, Bangladesh, p. 155.

Schotzing U., Debertin K. (1983) Photon emission probabilities per decay of ${ }^{226} \mathrm{Ra}$ and ${ }^{232} \mathrm{Th}$ equilibrium with their daughter products, Appl. Rad. Isotopes 34, 533-538.

Zafar M. (2000) Study on Sergestid Shrimp Acetes in the Vicinity of Mathamuhuri River Confluence, Bangladesh, Ph.D. thesis, University of Chittagong, Chittagong, Bangladesh.

Zafar M., Alam M.N., Chowdhury M.I, Kamal M., Siddiqui M.Z.H. (2004) Radionuclides in Scylla serrata (Forskal, 1775) of Chakaria Sundarban Area, Bangladesh, Asian Fish. Sci. 17, 261-270. 